\title{
Pengaruh Panjang, Bentuk, dan Jenis Batang pada Metode Pengapungan Batang dalam Mendeteksi Waktu Pemisahan Kerosin dan Air
}

\author{
Effect of Length, Shape, and Type of Rod on the Buoyancy Weighing-Bar Method in \\ Detecting the Separation Time of Kerosene and Water
}

\author{
Rondang Tambun*, Albert Novian Silaen, Indra Jaya Banjarnahor
}

Departemen Teknik Kimia, Fakultas Teknik, Universitas Sumatera Utara, Medan 20155, Indonesia

Email : rondang@usu.ac.id

\begin{abstract}
Abstrak
Penelitian ini bertujuan untuk mengaplikasikan Metode Pengapungan Batang (Buoyancy Weighing-Bar Method) dalam mendeteksi waktu pemisahan terbaik pada emulsi yang terdiri dua cairan yang berbeda densitas, yaitu kerosin dan air. Pada metode ini, perubahan massa batang yang digantung pada emulsi akan diukur seiring berjalannya waktu. Perubahan massa batang ini terjadi karena perpindahan massa gelembung yang disebabkan karena adanya perbedaan densitas cairan. Pada penelitian dikaji pengaruh jenis, bentuk, dan panjang batang dalam penentuan waktu pemisahan terbaik antara kerosin dan air dengan konsentrasi $2 \%$ kerosin dalam $98 \%$ air. Jenis batang yang digunakan yaitu aluminium, tembaga, perunggu dan besi dengan variasi bentuk batang yaitu silinder, prisma segi empat, prisma segi enam, dan sheet. Sementara variasi panjang batang adalah $210 \mathrm{~mm}$, $160 \mathrm{~mm}, 110 \mathrm{~mm}$ dan $60 \mathrm{~mm}$. Berdasarkan hasil yang diperoleh, waktu pemisahan kerosinair dapat ditentukan dengan metode pengapungan batang. Jenis batang yang paling akurat dalam menentukan waktu pemisahan terbaik antara kerosin dan air adalah perunggu dengan panjang $210 \mathrm{~mm}$. Pada variasi bentuk batang dihasilkan waktu pemisahan yang berdekatan untuk setiap bentuknya.
\end{abstract}

Kata kunci: buoyancy weighing bar, BWM, minyak dalam air, waktu pemisahan

\begin{abstract}
This study aims to apply the Buoyancy Weighing-Bar Method in detecting the best separation time for emulsions consisting of two different liquid densities, namely kerosene and water. In this method, the change in mass of the rods that are hung on the emulsion will be measured over time. Changes in rod mass occur due to bubble mass transfer due to differences in liquid density. The study examined the effect of rod type, rod shape and rod length in determining the best separation time between kerosene and water with a concentration of $2 \%$ kerosene in $98 \%$ water. The types of rods used are aluminum, copper, bronze and iron with a variety of rod shapes, namely cylinders, rectangular prisms, hexagon prisms, and sheets. While variations in rod length are $210 \mathrm{~mm}, 160 \mathrm{~mm}, 110 \mathrm{~mm}$ and 60 $\mathrm{mm}$. Based on the results obtained, the kerosene-water separation time can be determined by the Buoyancy Weighing-Bar Method. The most accurate type of rod in determining the best separation time between kerosene and water is bronze with a length of $210 \mathrm{~mm}$. In the variation of the rod shape, the resulting separation times are close together for each shape.
\end{abstract}

Keywords : buoyancy weighing bar, BWM, oil in water, separation time

\section{Pendahuluan}

Emulsi minyak dalam air digunakan pada beberapa proses industri seperti industri makanan, cat, dan kosmetik. Emulsi minyak dalam air ini juga dihasilkan pada proses penyulingan minyak dan petrokimia. Pada industri logam, emulsi minyak dalam air banyak digunakan untuk proses pendinginan. Proses daur ulang emulsi minyak dalam air adalah proses kompleks yang melibatkan koagulasi, flokulasi, pemisahan gravitasi, adsorpsi tetap dan teknik membran [1]. Pada proses daur ulang 
tersebut, perlu diketahui waktu pemisahan antara minyak dengan air sebagai salah satu parameter kunci karena mempengaruhi sifat emulsi dan stabilitasnya.

Untuk pengujian kemurnian suatu larutan yang telah teremulsi sangat dapat dilakukan dengan menggunakan Gas Chromathography. Penggunaaan Gas Chromathography ini memberikan hasil yang sangat akurat tetapi memerlukan biaya yang cukup mahal. Oleh karena itu, menggunakan metode lain yang dapat menentukan waktu pemisahan dengan biaya cukup murah sangat diperlukan. Salah satu metode yang dapat digunakan untuk menentukan waktu pemisahan cairan adalah Metode Pengapungan Batang (Buoyancy Weighing-Bar Method atau BWM) [2][3].

Pada penelitian ini, BWM akan mendeteksi perpindahan gelembung cairan akibat adanya perbedaan densitas. Metode ini digunakan untuk menentukan waktu pemisahan terbaik antara dua cairan yang berbeda densitas yaitu kerosin dan air.

\section{Teori}

Prinsip dari BWM adalah dengan menggunakan sebuah batang logam yang digantungkan pada emulsi, dimana massa batang tersebut akan berubah seiring berjalannya waktu dikarenakan terjadinya perpindahan massa gelembung berdasarkan perbedaan densitas [4][5][6][7].

Emulsi terdiri dari 2 fasa cair yang tidak menyatu yaitu antara fasa terdispersi dan fasa kontinu. Fasa terdispersi adalah fasa yang berperan dalam pembentukan gelembung dan fasa kontinu adalah fasa yang membentuk matriks dimana gelembung tersuspensi. Ada dua jenis tipe emulsi yaitu minyak dalam air (M/A) dimana gelembung dari minyak terdispersi dalam air, dan air dalam minyak (A/M) dimana gelembung dari air terdispersi dalam minyak [8].

Sifat dari emulsi bergantung pada volume fasa kontinu dan fasa terdispersi. Meningkatkan viskositas fasa kontinu maka akan meningkatkan kestabilan dari emulsi. Semakin besar ukuran gelembung dan semakin sedikit volume fasa kontinu, akan membuat emulsi kurang stabil [9].

Pada tangki berpengaduk, laju perpindahan massa antara sistem fasa cair-cair tidak hanya bergantung pada dinamika gerak dari dua cairan yang bercampur, tetapi lebih kepada ukuran dari gelembung. Ukuran gelembung dapat terbentuk dari pemecahan gelembung ataupun penggabungan gelembung. Pemecahan gelembung terjadi pada aliran turbulen. Penggabungan gelembung tergantung pada frekuensi tumbukan dan effisiensi penggabungan antar gelembung. Semakin besar fraksi fasa terdispersi, maka akan semakin besar tumbukan terjadi [10].

Kerusakan atau destabilisasi emulsi terjadi melalui tiga mekanisme utama yaitu creaming, flocculation dan coalescence. Creaming merupakan proses pemisahan yang terjadi akibat adanya gerakangerakan ke atas atau ke bawah. Hal ini terjadi karena adanya gaya gravitasi terhadap fase-fase yang berbeda densitasnya. Flocculation merupakan agregasi atau penyatuan dari gelembung. Pada flocculation tidak terjadi pemusatan film antar permukaan sehingga jumlah dan ukuran globula tetap. Terjadinya flocculation akan mempercepat terjadinya creaming. Coalescence adalah penggabungan gelembung menjadi gelembung yang lebih besar. Pada tahap ini terjadi pemusatan film antar permukaan sehingga ukuran gelembung berubah [11].

Ukuran gelembung yang kecil yang dihasilkan oleh homogenisasi dapat meningkatkan fasa terdispersi. Sebagai akibatnya viskositas semakin meningkat dan penyerapan emulsifier dapat meningkat. Ketidakcukupan emulsifier dalam menyelubungi permukaan gelembung akan menyebabkan coalescence. Pengemulsian juga membutuhkan waktu homogenisasi yang tepat. Intensitas dan lama proses pencampuran tergantung waktu yang diperlukan untuk melarutkan dan mendistribusikannya secara merata [11].

\section{Metodologi Penelitian}

Bahan yang digunakan pada penelitian adalah kerosin $\left(\rho=810 \mathrm{~kg} / \mathrm{m}^{3}\right)$ dan air $\left(\rho=1000 \mathrm{~kg} / \mathrm{m}^{3}\right)$.

Peralatan yang digunakan pada penelitian adalah neraca analitik FS AR-210 dengan ketelitian 0,0001 yang memiliki pengait di bawah, batang logam yang berfungsi sebagai pendeteksi perpindahan gelembung cairan yang terbuat dari aluminium $(\rho=2826,654$ $\left.\mathrm{kg} / \mathrm{m}^{3}\right)$, tembaga $\left(\rho=8916,787 \mathrm{~kg} / \mathrm{m}^{3}\right)$, perunggu $(\rho=$ $\left.9219,818 \mathrm{~kg} / \mathrm{m}^{3}\right)$, dan besi $\left(\rho=8016,630 \mathrm{~kg} / \mathrm{m}^{3}\right)$. Batang logam berjenis besi divariasikan dengan bentuk silinder, prisma segi empat, prisma segi enam dan sheet serta batang logam berjenis aluminium divariasikan dengan panjang $210 \mathrm{~mm}, 160 \mathrm{~mm}, 110$ $\mathrm{mm}$, dan $60 \mathrm{~mm}$. Sebagai metode pembanding untuk menentukan kemurnian cairan digunakan Gas Chromatography.

\section{Prosedur Penelitian}

Penelitian dilakukan dengan mencampurkan kerosin ke dalam air pada suhu $298 \mathrm{~K}$ (suhu kamar) sehingga terbentuk dua lapisan dengan perbandingan konsentrasi 2\% kerosin : $98 \%$ air. Dari pencampuran ini akan terbentuk 2 lapisan, yaitu lapisan atas (kerosin) dan lapisan bawah (air). Untuk mengetahui bahwa kerosin dan air sudah terpisah secara sempurna, maka digunakan BWM dengan memvariasikan panjang batang, bentuk batang, dan jenis batang. Pada metode ini, batang logam akan digunakan untuk mendeteksi perpindahan massa gelembung yang mengapung. Semua campuran diaduk menggunakan pengaduk khusus sebelum dilakukan pengukuran. Lama pengukuran maksimal selama 1 jam dan data direkam setiap interval 1 detik. 
Pada penelitian ini, untuk mengetahui kemurnian pemisahan dari kerosin dan air diuji dengan menggunakan gas chromatography.

Untuk menyiapkan suspensi, $1000 \mathrm{ml}$ campuran dimasukkan ke dalam gelas ukur. Dengan mengunakan tali/benang yang sangat ringan, batang yang sesuai dengan rancangan percobaan di atas digantung pada bagian bawah neraca analitik. Setelah diaduk, batang dimasukkan ke dalam suspensi, dan dicatat sebagai $\mathrm{t}=0$ detik. Hal ini berlangsung maksimal selama 1 jam.

\section{Hasil}

Pada penelitian ini, aplikasi BWM terhadap waktu pemisahan kerosin dan air dilakukan pada perbandingan konsentrasi antara kerosin dengan air sebesar 2\%: $98 \%$ yang divariasikan dengan panjang batang, bentuk batang dan jenis batang.

\section{Pengaruh Panjang Batang}

Gambar 1 merupakan pengaruh panjang batang dan waktu pemisahan terhadap massa batang. Batang yang digunakan terbuat dari aluminium berbentuk silinder dengan variasi panjang $60 \mathrm{~mm}, 110 \mathrm{~mm}, 160$ $\mathrm{mm}$ dan $210 \mathrm{~mm}$.

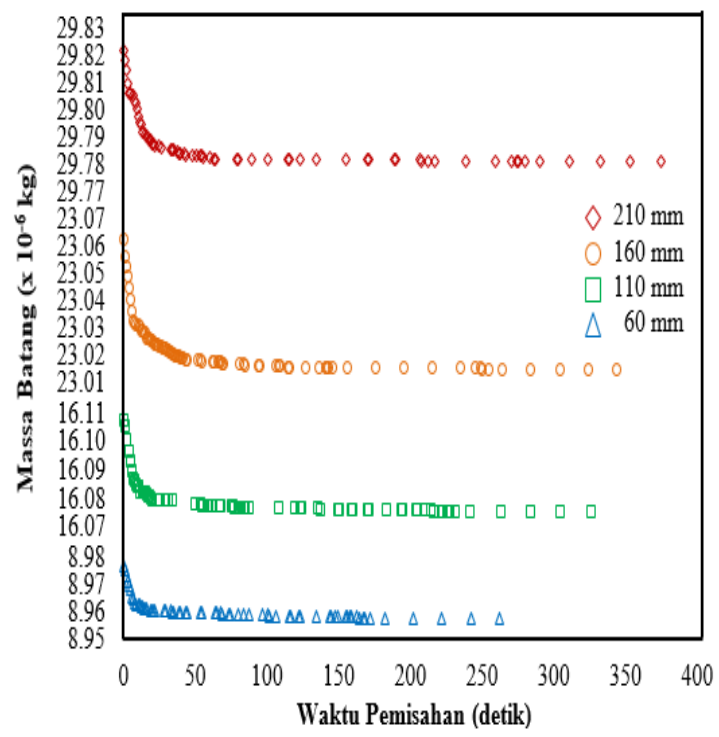

Gambar 1. Pengaruh panjang batang dan waktu pemisahan terhadap massa batang

Pada Gambar 1 dapat dilihat bahwa pada batang dengan panjang $60 \mathrm{~mm}$, massa batang menurun dengan cepat dimulai dari detik ke-0 hingga detik ke40 dan massa batang mulai menurun secara perlahan hingga konstan sampai detik ke-168. Pada detik ke168 massa batang sudah konstan yang menunjukkan bahwa kerosin dan air sudah terpisah. Pada batang dengan panjang $110 \mathrm{~mm}$, massa batang menurun dengan cepat dimulai dari detik ke-0 hingga detik ke-
46 dan massa batang mulai menurun secara perlahan hingga konstan sampai detik ke-216. Pada detik ke216 massa batang sudah konstan yang menunjukkan bahwa kerosin dan air sudah terpisah. Pada batang dengan panjang $160 \mathrm{~mm}$, massa batang menurun dengan cepat dimulai dari detik ke- 0 hingga detik ke44 dan massa batang mulai menurun secara perlahan hingga konstan sampai detik ke-251. Pada detik ke251 massa batang sudah konstan yang menunjukkan bahwa kerosin dan air sudah terpisah. Pada batang dengan panjang $210 \mathrm{~mm}$, massa batang menurun dengan cepat dimulai dari detik ke-0 hingga detik ke61 dan massa batang mulai menurun secara perlahan hingga konstan sampai detik ke-261. Pada detik ke261 massa batang sudah konstan yang menunjukkan bahwa kerosin dan air sudah terpisah.

Pada awal proses pemisahan, gelembung yang berukuran besar akan mengapung terlebih dahulu sehingga penurunan massa batang yang terjadi cukup besar. Semakin lama waktu proses pemisahan, maka penurunan massa batang semakin lambat dan pada akhirnya akan konstan karena pada saat tersebut semua gelembung baik gembung besar maupun gelembung kecil sudah mengapung [12].

Pada proses pemisahan minyak dalam air, terdapat perbedaan waktu pemisahan antara panjang batang yang digunakan. Hal ini dikarenakan semakin panjangnya batang yang digunakan, maka semakin luas area dalam mendeteksi perpindahan gelembung.

Pada penelitian ini, batang dengan panjang 210 $\mathrm{mm}$ yang massanya berubah secara perlahan hingga konstan membutuhkan waktu lebih lama dibandingkan batang dengan panjang $60 \mathrm{~mm}, 110$ $\mathrm{mm}$, dan $160 \mathrm{~mm}$. Hal ini menunjukkan bahwa, batang dengan panjang $210 \mathrm{~mm}$ lebih baik dalam mendeteksi perpindahan gelembung dibandingkan dengan panjang batang lainnya.

\section{Pengaruh Bentuk Batang}

Gambar 2 merupakan pengaruh bentuk batang dan waktu pemisahan terhadap waktu pemisahan. Batang yang digunakan terbuat dari besi dan panjang $210 \mathrm{~mm}$ dengan varisi bentuk silinder, prisma segi empat, prisma segi enam dan sheet.

Pada Gambar 2 dapat dilihat bahwa pada batang berbentuk silinder, massa batang menurun dengan cepat dimulai dari detik ke-0 hingga detik ke-72 dan massa batang mulai menurun secara perlahan hingga konstan sampai detik ke-365. Pada detik ke-365 massa batang sudah konstan yang menunjukkan bahwa kerosin dan air sudah terpisah. Pada batang berbentuk prisma segi empat, massa batang menurun dengan cepat dimulai dari detik ke-0 hingga detik ke-72 dan massa batang mulai menurun secara perlahan hingga konstan sampai detik ke-264.

Pada detik ke-264 massa batang sudah konstan yang menunjukkan bahwa kerosin dan air sudah terpisah. Pada batang berbentuk prisma segi enam, 
massa batang menurun dengan cepat dimulai dari detik ke-0 hingga detik ke-68 dan massa batang mulai menurun secara perlahan hingga konstan sampai detik ke-285. Pada detik ke-285 massa batang sudah konstan yang menunjukkan bahwa kerosin dan air sudah terpisah. Pada batang berbentuk sheet, massa batang menurun dengan cepat dimulai dari detik ke-0 hingga detik ke-72 dan massa batang mulai menurun secara perlahan hingga konstan sampai detik ke-318. Pada detik ke-318 massa batang sudah konstan yang menunjukkan bahwa kerosin dan air sudah terpisah.

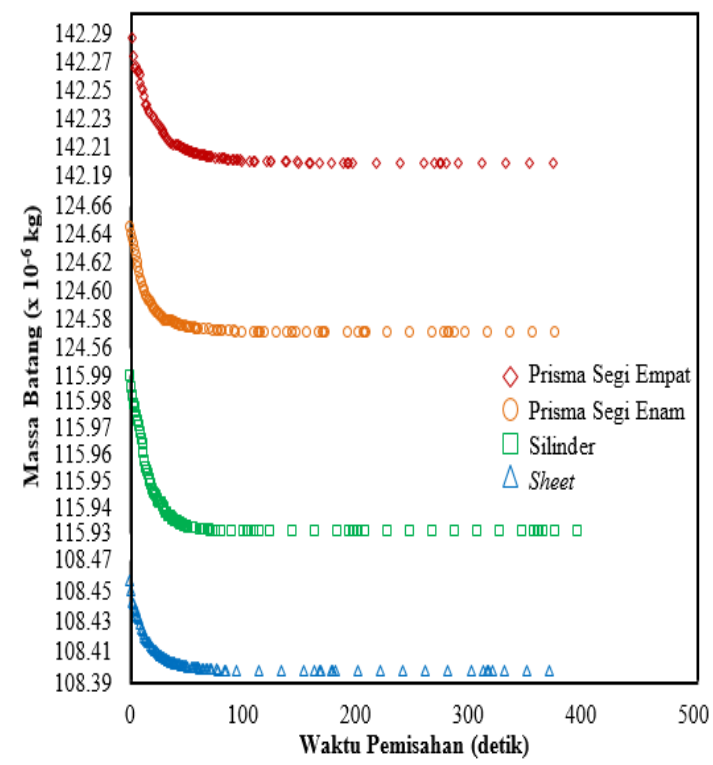

Gambar 2. Pengaruh bentuk batang dan waktu pemisahan terhadap massa batang

Pada penelitian ini, setiap bentuk batang mempunyai waktu perubahan massa batang yang berdekatan. Hal ini menunjukkan bahwa bentuk batang tidak memberikan pengaruh yang signifikan dalam penentuan waktu pemisahan.

\section{Pengaruh Jenis Batang}

Gambar 3 merupakan pengaruh jenis batang dan waktu pemisahan terhadap massa batang. Batang yang digunakan berbentuk silinder dan panjang $210 \mathrm{~mm}$ yang terbuat dari aluminium, tembaga, perunggu dan besi.

Pada gambar 3 dapat dilihat bahwa pada batang aluminium, massa batang menurun dengan cepat dimulai dari detik ke-0 hingga detik ke-61 dan massa batang mulai menurun secara perlahan hingga konstan sampai detik ke-261. Pada detik ke-261 massa batang sudah konstan yang menunjukkan bahwa kerosin dan air sudah terpisah. Pada batang tembaga, massa batang menurun dengan cepat dimulai dari detik ke-0 hingga detik ke-67 dan massa batang mulai menurun secara perlahan hingga konstan sampai detik ke-721. Pada detik ke-721 massa batang sudah konstan yang menunjukkan bahwa kerosin dan air sudah terpisah. Pada batang perunggu, massa batang menurun dengan cepat dimulai dari detik ke-0 hingga detik ke155 dan massa batang mulai menurun secara perlahan hingga konstan sampai detik ke-777. Pada detik ke777 massa batang sudah konstan yang menunjukkan bahwa kerosin dan air sudah terpisah. Pada batang besi, massa batangmenurun dengan cepat dimulai dari detik ke-0 hingga detik ke-72 dan massa batang mulai menurun secara perlahan hingga konstan sampai detik ke-365. Pada detik ke-365 massa batang sudah konstan yang menunjukkan bahwa kerosin dan air sudah terpisah.

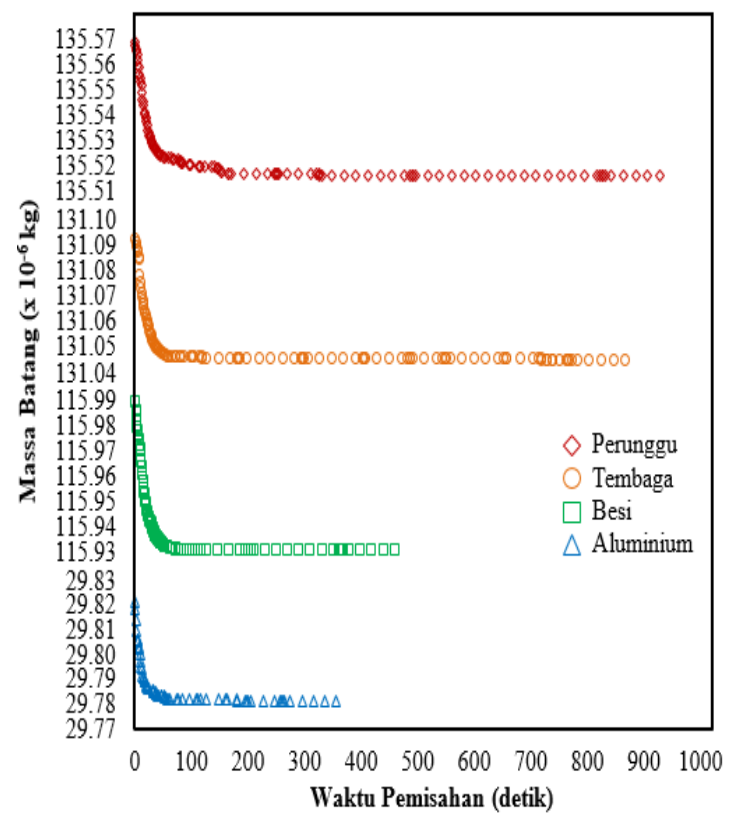

Gambar 3. Pengaruh jenis batang dan waktu pemisahan terhadap massa batang

Pada proses pemisahan minyak dalam air, terdapat perbedaan waktu pemisahan antara jenis batang yang digunakan. Hal ini dikarenakan adanya perbedaan massa jenis batang yang digunakan, dimana semakin besar massa jenis batang maka lebih baik dalam mendeteksi perpindahan gelembung tersebut.

Secara umum, penentuan keakuratan penggunaan panjang, bentuk dan jenis batang dibandingkan terhadap hasil pengukuran Gas Chromatography yang digunakan sebagai pembanding dalam penentuan pemisahan kerosin dan air. Sampel yang diambil untuk menguji kadar air yang awalnya sebesar $100 \%$ adalah sampel pada detik ke-50, ke-100, ke-400, dan detik ke-777. Pada detik ke-50 massa batang belum konstan dengan kadar air sebesar 98,3173\%. Demikian juga pada detik ke-100, massa batang masih belum konstan dengan kadar air sebesar 98,8079\%. Pada detik ke-400 massa batang sudah mulai konstan yang menandakan bahwa kerosin dan air sudah terpisah tetapi belum sempurna dengan kadar air sebesar 99,2513\%. Namun, massa batang tersebut 
masih tetap meningkat secara perlahan sampai detik ke-777 dengan kadar air didapat 99,7251\%.

Pada dasarnya, kadar kerosin untuk detik ke-50, detik ke-100, detik ke-400 dan detik ke-777 adalah sama untuk semua variasi jenis batang, namun pada penelitian ini hanya pada batang perunggu yang massanya berubah secara perlahan hingga konstan pada detik ke-777. Sementara itu pada batang aluminium, tembaga, dan besi mengalami perubahan massa hingga akhirnya konstan lebih cepat. Hal ini menunjukkan bahwa, batang perunggu lebih baik dalam mendeteksi perpindahan gelembung dibandingkan dengan jenis batang lainnya.

\section{Kesimpulan}

Kesimpulan yang diperoleh dari penelitian ini adalah bahwa Metode Pengapungan Batang (BWM) dapat dipakai untuk mendeteksi waktu pemisahan kerosin dan air pada rasio konsentrasi $2 \%$ kerosin : $98 \%$ air. Jenis batang yang paling efektif dalam menentukan waktu pemisahan kerosin dan air adalah perunggu, sementara panjang batang yang paling efektif dalam menentukan waktu pemisahan kerosin dan air adalah $210 \mathrm{~mm}$. Pada metode ini, variasi bentuk batang tidak berpengaruh secara signifikan dan semua bentuk batang memberikan hasil pengukuran yang hamper sama.

\section{Daftar Pustaka}

[1] L. Muruganandam, D. Kunal, and G. O. Melwyn, "Studies on droplet size distribution of oil-inwater emulsion in SMX static mixer," J. Appl. Fluid Mech., vol. 11, no. 1, pp. 107-114, 2018, doi: 10.29252/jafm.11.01.28151.

[2] R. Tambun, Y. Sibagariang, and J. Manurung, "Influence of the weighing bar size to determine optimal time of biodiesel-glycerol separation by using the buoyancy weighing-bar method," in IOP Conference Series: Materials Science and Engineering, 2018, vol. 309, no. 1, doi: 10.1088/1757-899X/309/1/012067.

[3] R. Tambun, P. Sibagariang, B. Alphantaria, and A. M. Rambe, "Droplet size distribution measurement of water in kerosene by the buoyancy weighing-bar method," in MATEC Web of Conferences, 2018, vol. 154, doi: 10.1051/matecconf/201815401016.

[4] E. Obata, Y. Ohira, and M. Ohta, "New measurement of particle size distribution by a buoyancy weighing-bar method," Powder Technol., vol. 196, no. 2, pp. 163-168, 2009, doi: 10.1016/j.powtec.2009.07.015.

[5] T. Motoi, Y. Ohira, and E. Obata, "Measurement of the floating particle size distribution by a buoyancy weighing-bar method," Powder Technol., vol. 201, no. 3, pp. 283-288, 2010, doi: 10.1016/j.powtec.2010.04.015.

[6] R. Tambun, K. Nakano, M. Shimadzu, Y. Ohira, and E. Obata, "Sizes influences of weighing bar and vessel in the buoyancy weighing-bar method on floating particle size distribution measurements," Adv. Powder Technol., vol. 23, no. 6, 2012, doi: 10.1016/j.apt.2011.12.002.

[7] R. Tambun, K. Furukawa, M. Hirayama, M. Shimadzu, S. Y. Yamanaka, and Y. Ohira, "Measurement and estimation of the particle size distribution by the buoyancy weighing-bar method and the rosin-rammler equation," $J$. Chem. Eng. Japan, vol. 49, no. 2, pp. 229-233, 2016, doi: 10.1252/jcej.14we129.

[8] T. K. Ghosh and B. R. Jasti, Theory and practice of contemporary pharmaceutics. New York: CRC Press, 2005.

[9] S. T. Beckett, "Physico-Chemical Aspects of Food Processing." Springer Science \& Business Media, 2012, doi: 10.1007/978-1-4613-1227-7.

[10] S. Maaß, A. Gäbler, A. Zaccone, A. R. Paschedag, and M. Kraume, "Experimental investigations and modelling of breakage phenomena in stirred liquid/liquid systems," Chem. Eng. Res. Des., vol. 85, no. 5 A, pp. 703709, 2007, doi: 10.1205/cherd06187.

[11] D. J. McClements, Food Emulsions : principles, practices, and techniques, Third Edit. London: CRC Press, 2015.

[12] Y. Mao, L. Yong, H. Tao, W. Shimin, and X. Yiqian, "In-situ measurement of droplet size distribution by light scattering method," Wuhan Univ. J. Nat. Sci., vol. 3, no. 4, pp. 418-422, 1998, doi: $10.1007 /$ bf02830042. 